\title{
PENGARUH UMUR DAN RIWAYAT KONTAK DENGAN KEJADIAN TBC PARU PADA ANAK DI PUSKESMAS PERIUKJAYA KOTA TANGERANG
}

\author{
Wasludin \\ Poltekkes Kemenkes Banten \\ Korespondensi: wasludin@poltekkesbanten.ac.id
}

\begin{abstract}
ABSTRAK
Penelitian ini dilatar belakangi masih tingginya penderita Tuberculosis (TBC) paru di Wilayah kerja Puskesmas Periuk Jaya Kota Tangerang tahun 2013 yaitu sebanyak 34 kasus terdiri dari 22 orang dewasa dan 12 orang anak, oleh karena itu, peneliti ingin mengetahui faktor umur, status imunisasi, status gizi, riwayat kontak, dan kesehatan rumah yang mempengaruhi kejadian TBC paru pada anak di Puskesmas Periuk Jaya Kota Tangerang.

Metode penelitian menggunakan analitik retrospektif dengan sampel total sampling menggunakan data primer yang didapatkan melalui wawancara, pengukuran dan observasi. Hasil penelitian diperoleh bahwa p-value umur dengan kejadian TBC paru 0,015 $(<0,05)$ artinya ada pengaruh umur terhadap kejadian TBC paru anak, nilai p-value riwayat kontak dengan kejadian TBC 0,015 $(<0,05)$, artinya ada pengaruh riwayat kontak terhadap kejadian TBC, p-value status imunisasi 0,168 $(>0,05)$, dan nilai p-value status gizi 0,168 (>0,05), artinya tidak ada pengaruh status imunisasi dan status gizi terhadap kejadian TBC.

Berdasar hasil tersebut disimpulkan bahwa umur lebih muda (0-5 tahun) dan riwayat kontak mempunyai pengaruh terhadap kejadian tbc paru, oleh karena itu disarankan agar petugas Puskesmas memberikan penyuluhan tentang cara mencegah penularan TBC paru dan memantau kesehatan rumah.
\end{abstract}

Kata kunci : Umur, riwayat kontak, tuberculosis paru

\section{EFFECT OF AGE AND CONTACT WITH HISTORY EVENTS PULMONARY TBC IN CHILDREN IN HEALTH PERIUKJAYA CITY TANGERANG}

\author{
Wasludin
}

\begin{abstract}
The background of this study is the high patient Tuberculosis (TBC) in the pulmonary region Puskesmas Periuk Jaya Tangerang City in 2013 as many as 34 cases consisted of 22 adults and 12 children, therefore, the researchers wanted to find out the factors of age, immunization status, status nutrition, contact history, and home health that affect the incidence of pulmonary tuberculosis in children in health centers Periuk Jaya Tangerang City. The method uses an analytic retrospective study with a total sampling, with the primary data obtained through interviews, observation and measurement. The result showed that the $p-v a l u e$ of age with pulmonary tuberculosis incidence $0.015(<0.05)$, meaning that there is an influence of age on the incidence of pulmonary tuberculosis children, p-value history of contact with a TB incidence of $0.015(<0.05)$, meaning that there is the influence of history contacts on the incidence of tuberculosis, p-value status of immunization 0.168 (>0.05), and p-value nutritional status 0.168 (>0.05), meaning ther immunization status and nutritional status, no influence of the incidence of tuberculosis.
\end{abstract}


Based on these results concluded that younger age (0-5 years) and history of contact has an influence on the incidence of pulmonary tuberculosis, therefore, recommended that health center staff to provide education on how to prevent the transmission of tuberculosis and home health monitoring.

Keywords : Tangerang, age, contact history, pulmonary tuberculosis

\section{PENDAHULUAN}

Tuberkulosis (TBC atau TB) adalah suatu penyakit infeksi yang disebabkan oleh bakteri Mikobakterium tuberkulosa, merupakan bakteri basil yang sangat kuat sehingga memerlukan waktu lama untuk mengobatinya. Indonesia menduduki peringkat ke-3 negara dengan jumlah penderita TB terbanyak di dunia setelah India dan China. Jumlah pasien TB di Indonesia adalah sekitar $5,8 \%$ dari total jumlah pasien TB dunia. Angka prevalensi TB di Indonesia pada tahun 2009 adalah 100 per 100.000 penduduk dan TB terjadi pada lebih dari $70 \%$ usia produktif.

Pemerintah Kota Tangerang telah melaksanakan berbagai program penanggulangan TBC, namun hingga akhir 2011 masih tercatat sebanyak 1.395 warga yang terkena TBC dan penderita TBC merupakan jumlah terbanyak diderita penduduk ketimbang penyakit lainnya seperti kaki gajah, Demam Berdarah Dengue (DBD), virus HIV/AIDS (Dinkes Kota Tangerang 2012)

Puskesmas Periuk Jaya juga telah melaksanakan Program Penanggulangan TBC paru antara lain yaitu pemberian imunisasi BCG pada bayi berusia kurang dari 2 (dua) bulan, peningkatan daya tahan tubuh denganperbaikan status gizi terutama bagi keluarga kurang mampu seperti pemberian bantuan beras, peningkatan kesehatan lingkungan pemukiman untuk mencegah perkembang biakan kuman TBC, mencegah penularan TBC di antara anggota keluarga dengan membatasi kontak dengan penderita TBC, strategi penemuan kasus baru TBC dan mengupayakan penderita agar tidak putus pengobatan atau Drop Out (DO) dengan memberikan penyuluhan sehingga terjadi Multi Drug Resistance (MDR).

Namun kenyataannya kasus TB paru di Puskesmas Periuk Jaya Kota Tangerang masih cukup tinggi. Hingga bulan Mei 2013 tercatat sebanyak 33 orang terdiri dari kasus dewasa 21 orang (BTA (+) 12 orang dan BTA (-) 9 orang dan kasus TB paru anak 12 orang. Hal ini menarik perhatian penulis untuk mengetahui lebih jauh tentang faktor umur, imunisasi, status gizi, riwayat kontak, dan kesehatan lingkungan terhadap kejadian TBC paru pada anak.

Tujuan penelitian ini adalah untuk memperoleh gambaran tentang faktor-faktor yang mempengaruhi kejadian TBC Paru pada anak di Puskesmas Periuk Jaya Kota Tangerang.

\section{METODE}

Jenis penelitian adalah penelitian observational analitik yang bertujuan untuk 
Wasludin. Pengaruh Umur dan Riwayat Kontak dengan Kejadian TPC Paru pada Anak.

mencari gambaran atau menggambarkan kejadian tuberculosis dan menganalisis faktorfaktor yang mempengaruhi terjadinya tuberculosis tersebut pada responden. Desain penelitian ini adalah case control retrospektif yaitu penelitian yang dilakukan untuk mengetahui/mencari apakah kasus (penderita) pernah terekspos (terpajan) oleh faktor resiko atau tidak, dengan kata lain bahwa penelitian ini bertujuan untuk mencari faktor resiko yang mempengaruhi terjadinya suatu kasus yaitu TB paru.

Instrumen yang dipergunakan untuk mengumpulkan data dalam penelitian ini adalah daftar pertanyaan untuk wawancara, daftar tilik untuk observasi dan studi dokumentasi. Populasi kasus pada penelitian ini adalah penderita TBC paru pada anak di wilayah kerja Puskesmas Periuk Jaya Kota Tangerang yang berobat Januari - Mei tahun 2013 sebanyak 12 orang dan populasi control yaitu anak-anak yang berada di wilayah sekitar kasus baik yang sakit atau tidak, sedangkan sampel dalam penelitian ini adalah dengan mengunakan total populasi

Data yang telah dikumpulkan, selanjutnya diolah secara univariat untuk melihat distribusi frekuensi variabel independen dan dependen dan analisis bivariat mengunakan metode Chi Square/Chi kuadrat $\left(\mathrm{X}^{2}\right)$ untuk menguji hubungan antara variabel independen dengan variabel dependent dan datanya berbentuk kategorik.

\section{HASIL PENELITIAN}

Berdasarkan penelitian di dapatkan hasil seperti yang tertera pada tabel berikut ini:

Tabel 1.

Distribusi Responden Berdasarkan umur dan Kejadian TBC Di Wilayah Kerja Puskesmas Periuk Jaya Kota Tangerang Tahun 2013

\begin{tabular}{|c|c|c|c|c|c|}
\hline \multirow{2}{*}{ Umur } & \multicolumn{2}{|c|}{ Kasus TBC } & \multirow{2}{*}{ Total } & \multirow{2}{*}{$\begin{array}{c}\text { OR } \\
95 \% \mathrm{CI}\end{array}$} & \multirow{2}{*}{$\begin{array}{c}\text { P- } \\
\text { Value }\end{array}$} \\
\hline & $\mathrm{Ya}$ & Tidak & & & \\
\hline $0-5$ th & 7 & 6 & 13 & \multirow{2}{*}{$\begin{array}{l}7,000 \\
1,65- \\
29,66\end{array}$} & \multirow[b]{2}{*}{0,015} \\
\hline $\begin{array}{c}>5-12 \\
\text { th }\end{array}$ & 5 & 30 & 35 & & \\
\hline Jumlah & 12 & 36 & 48 & & \\
\hline
\end{tabular}

Hasil uji statistik diperoleh p-value 0,015; maka dapat disimpulkan bahwa ada perbedaan proporsi penderita TBC antara responden yang berumur $0-5$ tahun dengan responden yang berumur lebih 5 tahun artinya ada pengaruh yang signifikan antara umur dengan kejadian TBC pada anak. Nilai OR 7,000 artinya responden yang berumur $0-5$ tahun mempunyai resiko 7 kali dapat terkena TBC dibandingkan dengan responden berumur antara lebih dari 5 tahun sampai dengan 12 tahun.

Tabel 2.

Distribusi Responden Berdasarkan Status Imunisasi dan Kejadian TBC Di Wilayah Kerja Puskesmas Periuk Jaya Kota Tangerang Tahun 2013

\begin{tabular}{|c|c|c|c|c|c|}
\hline \multirow{2}{*}{$\begin{array}{c}\text { Status } \\
\text { Imunisasi }\end{array}$} & \multicolumn{2}{|c|}{ Kasus TBC } & \multirow{2}{*}{ Total } & \multirow{2}{*}{$\begin{array}{c}\text { OR } \\
95 \% \mathrm{CI}\end{array}$} & \multirow{2}{*}{$\begin{array}{c}\text { P- } \\
\text { Value }\end{array}$} \\
\hline & $\mathrm{Ya}$ & Tidak & & & \\
\hline Tidak & 7 & 11 & 18 & \multirow{2}{*}{$\begin{array}{c}3,182 \\
0,826- \\
12,262\end{array}$} & \multirow{2}{*}{0,168} \\
\hline Imunisasi & 5 & 25 & 30 & & \\
\hline Jumlah & 12 & 36 & 48 & & \\
\hline
\end{tabular}


Hasil uji statistik diperoleh p-value 0,168; maka dapat disimpulkan bahwa tidak ada perbedaan proporsi responden $\mathrm{TBC}$ antara responden yang pernah imunisasi dengan responden yang tidak pernah imunisasi artinya tidak ada pengaruh yang signifikan antara status imunisasi dengan kasus TBC. Nilai OR 3,182 artinya responden yang tidak pernah imunisasi mempunyai resiko 3 kali terkena TBC dibandingkan dengan responden yang pernah imunisasi.

Tabel 3

Distribusi Responden Berdasarkan Status Gizi dan kejadian TBC Di Wilayah Kerja

Puskesmas Periuk Jaya Kota Tangerang Tahun 2013

\begin{tabular}{cccccc}
\hline & \multicolumn{2}{c}{ Kasus TBC } & & & \\
Status Gizi & Ya & Tidak & & OR & Potal \\
\cline { 2 - 4 } & & & & $\begin{array}{c}\text { P- } \\
\text { Value }\end{array}$ \\
\hline $\begin{array}{c}\text { Kurang/ } \\
\text { buruk }\end{array}$ & 7 & 11 & 18 & $\begin{array}{c}3,182 \\
0,826-\end{array}$ & 0,168 \\
\hline Baik & 5 & 25 & 30 & 12,262 & \\
\hline Jumlah & 12 & 36 & 48 & &
\end{tabular}

Hasil uji statistik diperoleh p-value 0,168; maka dapat disimpulkan tidak ada perbedaan proporsi kasus/kejadian TBC antara responden yang memiliki status gizi yang baik dengan responden yang memiliki status gizi kurang artinya tidak ada pengaruh yang signifikan antara status gizi dengan kejadian TBC. Nilai OR 3,182 artinya responden yang memiliki status gizi kurang/buruk mempunyai resiko lebih dari 3 kali terkena TBC dibandingkan dengan responden yang memiliki status gizi baik.

Tabel 4.

Distribusi Responden Berdasarkan

Riwayat Kontak dan Kejadian TBC Di

Wilayah Kerja Puskesmas Periuk Jaya Kota Tangerang Tahun2013

\begin{tabular}{|c|c|c|c|c|c|}
\hline \multirow{2}{*}{$\begin{array}{l}\text { Riwayat } \\
\text { Kontak }\end{array}$} & \multicolumn{2}{|c|}{ Kasus TBC } & \multirow{2}{*}{ Total } & \multirow{2}{*}{$\begin{array}{c}\text { OR } 95 \% \\
\text { CI }\end{array}$} & \multirow{2}{*}{$\begin{array}{c}\mathrm{P}- \\
\text { Value }\end{array}$} \\
\hline & $\mathrm{Ya}$ & Tidak & & & \\
\hline $\mathrm{Ya}$ & 7 & 6 & 13 & \multirow{2}{*}{$\begin{array}{c}7,000 \\
1,652- \\
29,666\end{array}$} & \multirow{2}{*}{0,015} \\
\hline Tidak & 5 & 30 & 35 & & \\
\hline Jumlah & 12 & 36 & 48 & & \\
\hline
\end{tabular}

Hasil uji statistik diperoleh p-value 0,015; maka dapat disimpulkan bahwa ada perbedaan proporsi kejadian $\mathrm{TBC}$ antara responden yang memiliki riwayat kontak dengan responden yang tidak memiliki riwayat kontak artinya ada pengaruh yang signifikan antara riwayat kontak terhadap kejadian TBC paru. Nilai OR 7,000 artinya responden yang pernah riwayat kontak dengan penderita TBC paru mempunyai resiko 7 kali terkena TBC dibandingkan dengan responden yang tidak ada riwayat kontak dengan penderita TBC paru.

\section{Tabel 5}

Distribusi Responden Berdasarkan Kesehatan Lingkungan (Rumah) dan kejadian TBC Di Wilayah Kerja Puskesmas Periuk Jaya Kota Tangerang Tahun 2013

\begin{tabular}{|c|c|c|c|c|c|}
\hline \multirow{2}{*}{$\begin{array}{l}\text { Kesehatan } \\
\text { Rumah }\end{array}$} & \multicolumn{2}{|c|}{ Kasus TBC } & \multirow{2}{*}{ Total } & \multirow{2}{*}{$\begin{array}{c}\text { OR } \\
95 \% \mathrm{CI}\end{array}$} & \multirow{2}{*}{$\begin{array}{c}\text { P- } \\
\text { Value }\end{array}$} \\
\hline & $\mathrm{Ya}$ & Tidak & & & \\
\hline $\begin{array}{l}\text { Tidak } \\
\text { sehat }\end{array}$ & 6 & 11 & 17 & \multirow{2}{*}{$\begin{array}{c}2,273 \\
0,598- \\
8,640\end{array}$} & \multirow[t]{2}{*}{0,384} \\
\hline Sehat & 6 & 25 & 31 & & \\
\hline Jumlah & 12 & 36 & 48 & & \\
\hline
\end{tabular}


Hasil uji statistik diperoleh p-value 0,384, maka dapat disimpulkan tidak ada perbedaan proporsi kejadian TBC antara responden yang memiliki rumah sehat dengan responden yang memiliki rumah tidak sehat artinya tidak ada pengaruh yang signifikan antara kesehatan lingkungan (rumah) dengan kejadian TBC paru. Nilai OR 2,273 artinya responden yang memiliki lingkungan (rumah) yang tidak sehat mempunyai resiko lebih 2 kali terkena TBC dibandingkan responden yang memiliki lingkungan (rumah) yang sehat.

\section{PEMBAHASAN}

Hasil penelitian diperoleh bahwa responden yang berumur $0-5$ tahun sebanyak $27,1 \%$ dan yang berumur lebih dari 5 tahun sampai dengan 12 tahun sebanyak $72,9 \%$, responden yang tidak memiliki riwayat kontak dengan penderita TBC paru sebanyak 72,9\%, dan responden yang memiliki riwayat kontak dengan penderita TBC paru sebanyak $27,1 \%$, reponden yang pernah imunisasi BCG sebanyak 62,5\%, dan responden yang tidak pernah imunisasi sebanyak 37,5\%. Responden yang memiliki status gizi baik sebanyak 62,5\%, dan responden yang memiliki status gizi yang kurang sebanyak 37,5\%. Responden yang memiliki rumah yang sehat sebanyak $64,6 \%$, dan responden yang memiliki rumah yang tidak sehat sebanyak $35,4 \%$.

Memperhatikan data diatas, terdapat frekuensi yang tidak jauh berbeda baik pada kategorik variabel umur, status imunisasi, status gizi, riwayat kontak maupun pada variabel kesehatan lingkungan. Hal ini kemungkinan terjadi karena karakteristik sampel relatif sama atau perbedaannya tidak mencolok, baik pada umur, status imunisasi, status gizi, riwayat kontak, maupun kesehatan lingkungan (rumah) dalam kejadian TBC paru. Pembahasan hasil penelitian disajikan sebagai berikut:

\section{Pengaruh umur dan riwayat kontak terhadap kejadian TBC}

Hasil analisis pengaruh umur terhadap kejadian TBC diperoleh data bahwa terdapat 7 dari 13 responden yang berumur $0-5$ tahun menderita TBC paru dan pada responden yang berumur lebih dari 5 tahun sampai dengan 12 tahun terdapat 5 dari 35 responden menderita TBC paru. Hasil uji statistik diperoleh p-value 0,015; maka dapat disimpulkan bahwa ada perbedaan proporsi penderita TBC antara responden yang berumur $0-5$ tahun dengan responden yang berumur lebih 5 tahun artinya ada pengaruh yang signifikan antara umur dengan kejadian TBC pada anak. Nilai OR 7,000 artinya responden yang berumur $0-5$ tahun mempunyai resiko 7 kali dapat terkena TBC dibandingkan dengan responden berumur antara lebih dari 5 tahun sampai dengan 12 tahun.

Hal ini bisa terjadi karena berhubungan dengan kekebalan tubuh anak berkaitan dengan umur, anak lebih dari 5 tahun sudah bisa melakukan perilaku hidup bersih dan sehat, mencegah terjadinya penularan dengan membatasi kontak dengan penderita TBC, telah bisa memilih dan mengkonsumsi 
makanan yang bergizi dan melakukan olah raga dengan baik untuk meningkatkan kebugaran dan kesehatannya.

Hasil analisis pengaruh riwayat kotak terhadap kejadian TBC paru diperoleh data bahwa terdapat 5 dari 35 responden yang tidak memiliki riwayat kontak dengan penderita TBC paru tetapi menderita TBC paru, sedangkan pada responden yang ada riwayat kontak dengan penderita TBC, terdapat 7 dari 13 responden menderita TBC paru. Hasil uji statistik diperoleh p-value 0,015; maka dapat disimpulkan bahwa ada perbedaan proporsi kejadian TBC antara responden yang memiliki riwayat kontak dengan responden yang tidak memiliki riwayat kontak artinya ada pengaruh yang signifikan antara riwayat kontak terhadap kejadian TBC paru. Nilai OR 7,000 artinya responden yang pernah riwayat kontak dengan penderita TBC paru mempunyai resiko 7 kali terkena TBC dibandingkan dengan responden yang tidak ada riwayat kontak dengan penderita TBC paru.

Hal ini sesuai dengan hasil penelitian Rahayu (2009) dan selaras dengan pendapat Kartasasmita (2002) yang menyatakan bahwa "setiap orang desawa dengan Basil Tahan Asam (BTA) Positif akan menularkan ke 10 orang di lingkungannya".

Pernyataan tersebut juga ditegaskan oleh Rosmayudi (2002) bahwa "Sumber penularan TBC yang paling berbahaya adalah penderita TBC dewasa. Kasus seperti ini sangat infeksius dan dapat menularkan melalui batuk, bersin, dan percakapan.
Semakin sering dan lama kontak, semakin besar pula kemungkinan terjadi penularan”.

\section{Pengaruh status imunisasi, status gizi, dan kesehatan rumah terhadap Kejadian TBC}

Hasil analisis pengaruh status imunisasi terhadap kejadian TBC diperoleh data bahwa terdapat 5 dari 25 responden yang pernah imunisasi menderita TBC paru dan 7 dari 18 responden yang tidak pernah imunisasi menderita TBC paru. Hasil uji statistik diperoleh p-value 0,168; maka dapat disimpulkan bahwa tidak ada perbedaan proporsi responden TBC antara responden yang pernah imunisasi dengan responden yang tidak pernah imunisasi artinya tidak ada pengaruh yang signifikan antara status imunisasi dengan kasus TBC. Nilai OR 3,182 artinya responden yang tidak pernah imunisasi mempunyai resiko 3 kali terkena TBC dibandingkan dengan responden yang pernah imunisasi.

Dalam hasil penelitian ini menunjukkan bahwa status imunisasi tidak ada hubungan dengan kejadian TBC. Hasil ini sejalan dengan hasil penelitian Rahayu (2009) yang menyatakan tidak ada hubungan antara status imunisasi dengan hasil pemeriksaan BTA. Kenyataan ini bisa terjadi dan patut dipercaya karena tingkat efektivitas imunisasi tidak sempurna, yaitu hanya berkisar 70-80\%, (Sri Rejeki, 2005).

Meskipun demikian, proporsi responden yang pernah imunisasi lebih kecil terjadinya TBC dibandingkan dengan responden yang tidak pernah imunisasi. Hal ini selaras dengan pendapat Nyarko et al (2001) yaitu "bila 
dibadingkan, resiko kematian anak yang menerima vaksin dengan yang tidak menerima vaksin kira-kira 1: 9 sampai 1: 4".

Pendapat lain juga menyatakan bahwa “imunisasi dapat mengontrol penyakti TBC agar tidak menjadi lebih berat. Imunisasi ini akan memberikan kekebalan aktif terhadap penyakit TBC" (Sri Rejeki, 2005).

Hasil analisis pengaruh status gizi terhadap kejadian TBC diperoleh data bahwa terdapat 5 dari 30 responden yang memiliki status gizi baik menderita TBC paru, dan pada responden yang memiliki status gizi kurang terdapat 7 dari 18 responden menderita TBC paru. Hasil uji statistik diperoleh p-value 0,168; maka dapat disimpulkan bahwa tidak ada perbedaan proporsi kasus/kejadian TBC antara responden yang memiliki status gizi yang baik dengan responden yang memiliki status gizi kurang artinya tidak ada pengaruh yang signifikan antara status gizi dengan kejadian TBC. Nilai OR 3,182 artinya responden yang memiliki status gizi kurang/buruk mempunyai resiko lebih dari 3 kali terkena TBC dibandingkan dengan responden yang memiliki status gizi baik.

Meskipun dalam penelitian ini menunjukkan bahwa status gizi tidak ada pengaruh terhadap kejadian TBC paru, namun proporsi responden yang memiliki status gizi yang kurang baik, lebih banyak yang terkena TBC dan akan memperberat keadaan dan memperlambat penyembuhan TBC.

Hasil analisis pengaruh kesehatan lingkungan (rumah) terhadap kejadian TBC diperoleh data bahwa terdapat 6 dari 31 responden yang memiliki rumah sehat menderita TBC paru, sedangkan pada responden yang memiliki rumah tidak sehat terdapat 6 dari 17 responden menderita TBC paru. Hasil uji statistik diperoleh p-value 0,384, maka dapat disimpulkan tidak ada perbedaan proporsi kejadian TBC antara responden yang memiliki rumah sehat dengan responden yang memiliki rumah tidak sehat artinya tidak ada pengaruh yang signifikan antara kesehatan lingkungan (rumah) dengan kejadian TBC paru. Nilai OR 2,273 artinya responden yang memiliki lingkungan (rumah) yang tidak sehat mempunyai resiko lebih 2 kali terkena TBC dibandingkan responden yang memiliki lingkungan (rumah) yang sehat.

Sesuai dengan pendapat Dewanti (Kompas, 27 Februari 2009) yang menyatakan bahwa "lingkungan yang kurang bersih dan tempat tinggal yang tidak sehat juga dapat menambah jumlah penderita TBC dan penyakit menular lainnya". Peningkatan kesehatan lingkungan (rumah) tidak selamanya menyebabkan perubahan kejadian TBC, namun hubungan positif antara kedua variabel ini telah terbukti dalam hasil penelitian yang telah dilakukan Rahayu (2009)

\section{SIMPULAN}

Hasil uji statistik umur diperoleh p-value 0,015, dan OR 7.000; maka ada pengaruh antara umur dengan kejadian TBC pada anak dan responden yang berumur $0-5$ tahun mempunyai resiko 7 kali dapat terkena TBC 
dibandingkan dengan responden berumur antara lebih dari 5 tahun sampai dengan 12 tahun, dan hasil uji statistik riwayat kontak diperoleh p-value 0,015 dan OR 7.000; maka dapat disimpulkan ada pengaruh antara riwayat kontak dengan kejadian $\mathrm{TBC}$ dan responden yang pernah kontak dengan penderita TBC paru mempunyai resiko 7 kali terkena TBC dibandingkan dengan responden yang tidak ada riwayat kontak dengan penderita TBC paru.

Hasil uji statistik status gizi diperoleh pvalue 0,168 ; artinya tidak ada pengaruh yang signifikan antara status gizi dengan kejadian TBC, hasil uji statistik imunisasi diperoleh pvalue 0,168 ; artinya tidak ada pengaruh yang signifikan antara imunisasi dengan kejadian TBC, dan hasil uji statistik kesehatan rumah diperoleh p-value 0,384; artinya tidak ada pengaruh yang signifikan antara kesehatan lingkungan (rumah) dengan kejadian TBC.

\section{DAFTAR PUSTAKA}

1. Azwar Azrul, Metodologi Penelitian Kedokteran dan Kesehatan Masyarakat, Binarupa Aksara - Jakarta, 1993,

2. Brunner \& Suddarth, Buku Ajar Keperawatan Medikal Bedah, Edisi 8 Vol.1, penerbit EGC - Jakarta, 2002

3. Chazizah Gusnita - detikNews. 2010. www.medicastore.com/med/index Diunduh Pukul 15.00 WIB, Tanggal 29 Mei 2011.

4. Depkes RI. Penanggulangan TB Paru. Edisi 2. Jakarta : Depkes RI, 2007
5. Ngastiyah, Perawatan Anak Sakit, penerbit EGC - Jakarta, 1997

6. Omyosa, www. premium news wordpress theme.co.id. 2009. Diunduh Pukul 20.00 WIB, Tanggal 29 Mei 2011

7. Pratiknya, Ahmad Watik. Dasar-Dasar Metodologi Penelitian Kedokteran dan Kesehatan. PT Raja Grafindo Persada. Jakarta, 2000

8. Profil Kesehatan Kota Tangerang Tahun 2011, Dinas Kesehatan Kota Tangerang.. Dinkes Kota Tangerang, 2012

9. Rosmayudi, Diagnosis dan Pengobatan Tuberkulosis pada Bayi dan Anak, Bagian Ilmu Penyakit Anak Fakultas Kedokteran Universitas Padjajaran, Bandung 2002

10. Sudoyo, Aru W. dkk, 2006. Buku Ajar Ilmu Penyakit Dalam. Jakarta: Pusat Penerbitan Ilmu Penyakit Dalam Fakultas Kedokteran Universita Indonesia.

11. Tambayong, Jan, Patofisiologi untuk Keperawatan, penerbit EGC - Jakarta, 2000 